\title{
EVALUATION OF RELATION BETWEEN INTERPERSONAL VIOLENCE AND DRUG ABUSE ON CASES ATTENDED TO MENOUFIA UNIVERSITY HOSPITAL (A PROSPECTIVE STUDY)
}

Reham Hassan El- Farouny ${ }^{a}$ and Nagwa Mahmoud Habib ${ }^{a}$

${ }^{\mathrm{a}}$ Forensic Medicine and Clinical Toxicology Department, Faculty of Medicine- Menoufia University, Egypt

First author: Reham Hassan El- Farouny. E-mail address: dr_reham2004@yahoo.com Second author, Corresponding author: Nagwa Mahmoud Habib. E-mail addresses: Nagwa_habib@yahoo.com

\begin{abstract}
Background: Drug abuse and interpersonal violence are strongly linked to one another. The person's addiction to drugs increases the chances of being a perpetrator of violence or a victim to it. Illicit drugs use is recognized as a contributing factor to nearly all types of injuries due to the physical and mental impacts of illegal drugs on mind and behavior.

Objectives: This work aimed to study the relation between alleged injuries due to violence and drug abuse in cases who attended to Menoufia University Hospital to take a medicolegal report; also to study the prevalence and pattern of drugs of abuse among these cases within six months period of the study.

Subjects and methods: This cross sectional study was conducted on 500 individuals between 12 - 55 years after taking informed consent. A clinical sheet was designed for all cases including: sociodemographic data, history taking, clinical assessment, type, site and severity of injury. Questionnaire on drug abuse was fulfilled by every case. Cases were divided according to the severity of injury to mild, moderate, serious and fatal cases. Urine samples were collected from every case for toxicological laboratory screening tests by using immunoassays rapid tests.

Results: Males represented $90 \%$ of cases. $66 \%$ of the cases were in the age group 18-40 years, most of them did not work (73.2\%), and with an average qualification $(38 \%)$ or illiterate $(33.2 \%)$, the majority of whom lived in rural areas $(65 \%)$ and $70.8 \%$ of cases were involved in previous legal troubles. The highest percentage of injuries was due to blunt instruments (73.2\%). Most of the injuries had moderate score of ISS $(83.2 \%)$ and $14.4 \%$ of cases were admitted to the hospital.

Conclusion: Cannabis represented the highest percent of drug abuse, followed by cannabis and tramadol, while morphine derivatives were the least commonly used. The study recommends urine screening for all cases of injures due to violence. Also more accurate equipment and techniques should be used to determine the level of the substances in blood; thus monitoring substance abuse trends and quickly identifying emerging problems.
\end{abstract}

Key words: injuries, violence, drug abuse, relation, Menoufia 


\section{INTRODUCTION:}

Interpersonal violence and drug abuse are major challenges that are strongly connected. Drug abuse can elevates the dangers of being both a victim and/or assailant of violent acts, whereas involvement in violent acts may increase the dangers of starting illegal drug use. Argument precedes whether the relationship between drugs and violence is causal or an association, as both share the same risk factors (Atkinson et al., 2009). Although a clear relationship exists between drugs and violent behavior, the nature of this relation is multifactorial. In 1989, Goldstein et al. supposed three categories to describe the factors that link drugs and violence; these links include direct pharmacological effects of drugs, indirect economic reasons when addicts start robbery or other violent crimes in order to finance their drug use and finally indirect systemic link as violence within illicit drug markets (Goldstein et al., 1989; Harford et al., 2016). Use of illicit drugshas been recognized as a contributing factor to about all types of injuries including interpersonal violence, homicides, suicides, road traffic accidents, gunshot injuries and sexual crimes (Pérez et al., 2009). The physical and mental impacts of illegal drugs, such as cognitive impedance, agitation and hostility, increase hazard for aggressive behavior and disable the decisionmaking and communication skills essential to avoid violence (McGinty et al., 2016). Death from the utilization of these illegal drugs likes the peak of an ice mountain, so that once utilize of such substances can have unpredictable influences and sever harms to the brain and a cause of cardiovascular diseases, gastrointestinal disorders, harm to other vital organs and unsafe sexual behaviors, influence on family connections and violent behaviors (Harford et al., 2016). The World Health Organization, the United Nations Office on Crime and Drugs, and the Institute for Health Metrics and Evaluation reported that the mortality rate associated with substance use was highest in low and middle income countries. Furthermore in 2015; the estimated prevalence of alcohol use in the adult population was $18.3 \%$; and prevalence of daily tobacco smoking was $15.2 \%$. Moreover; substance-attributable mortality rates were $110.7,33$, and 6.9 deaths per 100,000 people for tobacco, alcohol, and illicit drugs, respectively (Peacock et al., 2017).

Objectives: This study aimed to study the relation between alleged injuries due to violence cases and drug abuse in injured cases due to violence attended to Menoufia University Hospital to take a medicolegal report about the situation. In addition to study the prevalence and pattern of drugs of abuse among these cases within six months (from 1 August 2017 to 31 January 2018). 
SUBJECTS \& METHODS

The study was a cross sectional prospective study conducted over cases attended to Menoufia University Hospital with alleged violent injuries asking for medicolegal report certificate in the period between $1^{\text {st }}$ of August 2017 to $31^{\text {th }}$ of January 2018, after approval by the Ethical Committee of Faculty of Medicine, Menoufia University

Inclusion criteria: All injured subjects between 12-55 years old presenting with alleged recent violent injuries i.e. intentional, either involved in a fight or being a victim of an assault; injured subjects who give signed written informed consent after explaining to them the aim of the study.

Exclusion criteria: All injured subjects younger than 12 years old or older than 55 years old, injured subjects presenting with non-violent injuries i.e. unintentional (road traffic accidents, work place injuries, sport injuries), injured subjects who refuse to sign the consent and injured subjects who received painkiller or avoided to continue the sampling process.

A clinical sheet was designed for all cases including: sociodemographic data, history taking, clinical assessment, type, site and severity of injury. Questionnaire on drug abuse was fulfilled by every case. Urine samples were collected for toxicological laboratory screening tests by using immunoassays rapid tests within 6 hours from onset of trauma. Injured subjects were classified according to severity of injury and anatomical distribution by injury severity score (ISS) based on the Abbreviated Injury Scale (AIS). This anatomical-based coding system classifies injuries in each of nine body regions using an ordinal scale of 1-6, with 1 as least severe and 6 as most severe. 1 accounts for cases that don't need treatment, 2 accounts for cases that need only outpatient treatment, 3 for cases that need non-ICU admission, 4 for cases needing ICU observation and basic treatment, 5 for cases that go for intubation, mechanical ventilation and blood pressure support, 6 for cases of unsurvivable injuries. The ISS is determined by summing the squares of the highest AIS rating (up to 5) for each of the three most severely injured body areas. If any of the three scores is 6, the score is automatically set at 75 . Consequently, ISS can take values between 1 and 75 (CordovillaGuardia et al., 2017).

Statistical Analysis: The data collected were tabulated and statistically analyzed using a personal computer with Statistical Package of Social Science (SPSS) version 20 and the following statistics were applied: descriptive statistics as number and percentage and analytic statistics by chi square test $\left(\chi^{2}\right.$ test). $P$ value greater than 0.05 was considered statistically non-significant. $P$ value less than 0.05 was considered statistically significant. $P$ value less than 0.001 was considered statistically highly significant (Dawson and Trapp, 2001). 


\section{RESULTS}

Table 1: Number and percentage of risk factors of the studied injured subjects attended to Menoufia University Hospital

\begin{tabular}{|c|c|c|c|}
\hline & Value & No. & $\%$ \\
\hline \multirow{3}{*}{ Age } & $12-<18 y$ & 69 & $13.8 \%$ \\
\hline & $18-<40 y$ & 330 & $66 \%$ \\
\hline & $40-\leq 55 \mathrm{y}$ & 101 & $20.2 \%$ \\
\hline \multirow{2}{*}{ Sex } & Male & 450 & $90 \%$ \\
\hline & Female & 50 & $10 \%$ \\
\hline \multirow{5}{*}{ Job } & Student & 63 & $12.6 \%$ \\
\hline & Not working & 226 & $45.2 \%$ \\
\hline & Laborer & 148 & $29.6 \%$ \\
\hline & Civil employee & 54 & $10.8 \%$ \\
\hline & Professional & 9 & $1.8 \%$ \\
\hline \multirow{4}{*}{ Education } & illiterate & 80 & $16 \%$ \\
\hline & Just Read \&write & 166 & $33.2 \%$ \\
\hline & Technical education & 190 & $38 \%$ \\
\hline & Higher & 64 & $12.8 \%$ \\
\hline \multirow{2}{*}{ Residence } & Rural & 325 & $65 \%$ \\
\hline & Urban & 175 & $35 \%$ \\
\hline \multirow{2}{*}{$\begin{array}{c}\text { History of } \\
\text { smoking }\end{array}$} & Yes (moderate to heavy) & 313 & $62.6 \%$ \\
\hline & No & 187 & $37.4 \%$ \\
\hline
\end{tabular}

Table 2: Frequency distribution of the studied injured subjects attended to Menoufia University Hospital in relation to circumstances of injury, history of previous legal troubles, and results of drug screening tests

\begin{tabular}{|c|c|c|c|}
\hline & Value & No. & $\%$ \\
\hline \multirow{2}{*}{$\begin{array}{c}\text { Circumstances of } \\
\text { injury }\end{array}$} & $\begin{array}{c}\text { Involved in a fight } \\
\text { (aggressor) }\end{array}$ & 230 & $46 \%$ \\
\cline { 2 - 4 } & Victim to an assault & 270 & $54 \%$ \\
\hline \multirow{2}{*}{ Previous legal troubles } & Yes & 146 & $29.2 \%$ \\
\cline { 2 - 4 } & No & 354 & $70.8 \%$ \\
\hline \multirow{2}{*}{$\begin{array}{c}\text { Results of drug } \\
\text { screening tests }\end{array}$} & Positive & 262 & $52.4 \%$ \\
\cline { 2 - 4 } & Negative & 238 & $47.6 \%$ \\
\hline
\end{tabular}




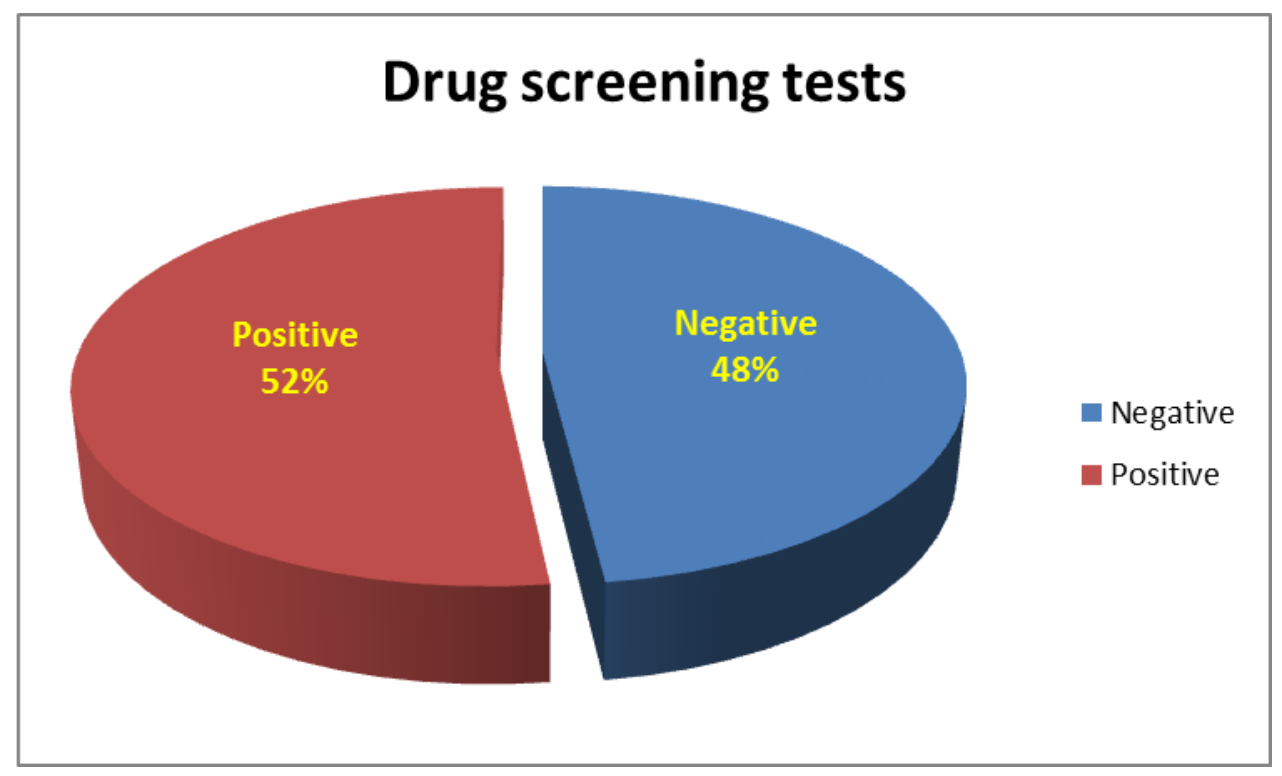

Fig 1: Results of drug screening tests as regard positive or negative in injured subjects

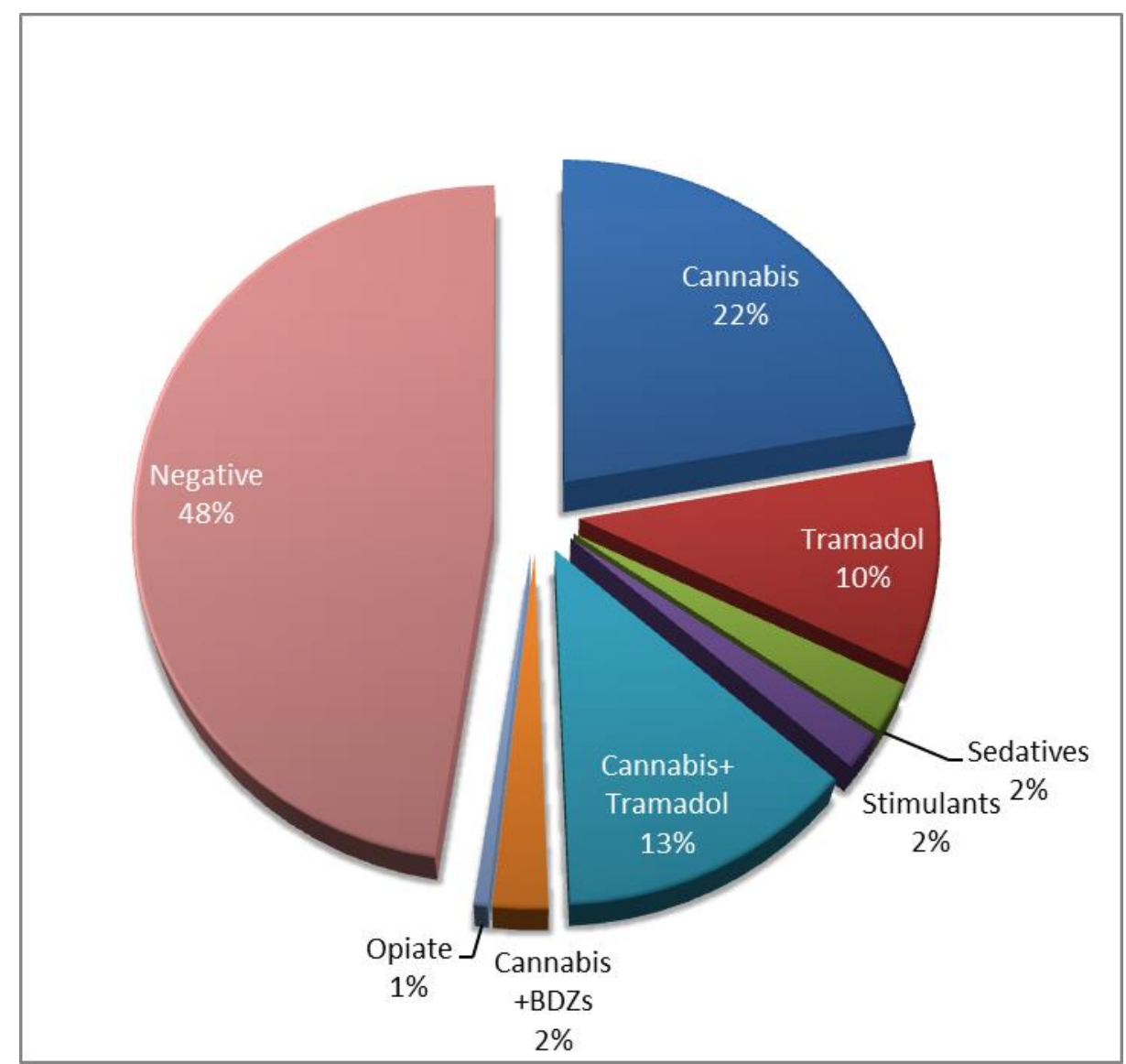

Fig 2: Types of drugs of abuse detected in injured subjects 
Table 3: Injury pattern of the studied injured subjects attended to Menoufia University Hospital

\begin{tabular}{|c|c|c|c|}
\hline & Value & No. & $\%$ \\
\hline \multirow{4}{*}{$\begin{array}{c}\text { Type of } \\
\text { instrument }\end{array}$} & Sharp & 78 & $15.6 \%$ \\
\hline & Blunt & 366 & $73.2 \%$ \\
\hline & Both sharp and blunt & 43 & $8.6 \%$ \\
\hline & Firearm weapon & 13 & $2.6 \%$ \\
\hline \multirow{8}{*}{$\begin{array}{c}\text { Type of } \\
\text { external } \\
\text { injury }\end{array}$} & Abrasions & 21 & $4.2 \%$ \\
\hline & Contusions & 64 & $12.8 \%$ \\
\hline & Abraded contusions & 12 & $2.4 \%$ \\
\hline & Contused wounds & 65 & $13 \%$ \\
\hline & Cut wounds & 61 & $12.2 \%$ \\
\hline & Stab wounds & 15 & $3 \%$ \\
\hline & More than one type & 249 & $49.8 \%$ \\
\hline & Firearm wounds & 13 & $2.6 \%$ \\
\hline \multirow{5}{*}{$\begin{array}{c}\text { Type of } \\
\text { internal } \\
\text { injury }\end{array}$} & Fracture & 46 & $9.2 \%$ \\
\hline & Hemorrhage & 46 & $9.2 \%$ \\
\hline & $\begin{array}{l}\text { Cut tendons/ Blood } \\
\text { vessels }\end{array}$ & 9 & $1.8 \%$ \\
\hline & Combined & 5 & $1 \%$ \\
\hline & Nothing & 394 & $78.8 \%$ \\
\hline \multirow{5}{*}{$\begin{array}{l}\text { Site of } \\
\text { injury }\end{array}$} & Head and neck & 117 & $23.4 \%$ \\
\hline & Chest & 14 & $2.8 \%$ \\
\hline & Extremities & 95 & $19.0 \%$ \\
\hline & Back & 11 & $2.2 \%$ \\
\hline & More than one site & 263 & $52.6 \%$ \\
\hline \multirow{5}{*}{ ISS } & Minor & 3 & $0.6 \%$ \\
\hline & Moderate & 416 & $83.2 \%$ \\
\hline & Serious & 46 & $9.2 \%$ \\
\hline & Sever & 32 & $6.4 \%$ \\
\hline & Un survivable & 3 & $0.6 \%$ \\
\hline
\end{tabular}

Table 4: Chi square statistical analysis of the relation between results of drug screening tests and different age groups

\begin{tabular}{|c|c|c|c|c|c|}
\hline \multicolumn{2}{|c|}{ Age } & \multicolumn{2}{|c|}{ Results of drug screening tests } & \multirow[t]{2}{*}{$\chi^{2}$} & \multirow[t]{2}{*}{$\mathbf{P}$} \\
\hline & & Positive & Negative & & \\
\hline \multirow{2}{*}{$12-<18 y$} & No & 18 & 51 & \multirow{8}{*}{15.5} & \multirow{8}{*}{$\begin{array}{c}* * \\
0.001\end{array}$} \\
\hline & $\%$ & $6.9 \%$ & $21.4 \%$ & & \\
\hline \multirow{2}{*}{$18-<40 y$} & No & 179 & 151 & & \\
\hline & $\%$ & $68.3 \%$ & $63.4 \%$ & & \\
\hline \multirow{2}{*}{$40-\leq 55 y$} & No & 65 & 36 & & \\
\hline & $\%$ & $24.8 \%$ & $15.1 \%$ & & \\
\hline \multirow{2}{*}{ Total } & No & 262 & 238 & & \\
\hline & $\%$ & $100 \%$ & $100 \%$ & & \\
\hline
\end{tabular}

** $P$ value $<0.01=$ highly significant 
Table 5: Chi square statistical analysis of the relation between type of abused drug and circumstances of injury

\begin{tabular}{|c|c|c|c|c|c|c|c|c|c|c|c|}
\hline \multirow{2}{*}{\multicolumn{2}{|c|}{$\begin{array}{c}\text { Circumstances of } \\
\text { injury }\end{array}$}} & \multicolumn{8}{|c|}{ Type of abused drug } & \multirow[b]{2}{*}{$\chi^{2}$} & \multirow[b]{2}{*}{$P$} \\
\hline & & $\begin{array}{l}\text { Cannabi } \\
\quad s\end{array}$ & $\begin{array}{c}\text { Tramad } \\
\text { ol }\end{array}$ & $\begin{array}{c}\text { Sedative } \\
\mathrm{s}\end{array}$ & $\begin{array}{l}\text { Stimulant } \\
\mathrm{s}\end{array}$ & $\begin{array}{c}\text { Cannabis } \\
+ \\
\text { Tramadol }\end{array}$ & $\begin{array}{c}\text { Cannabis } \\
+ \text { BDZ }\end{array}$ & $\begin{array}{c}\text { Opiat } \\
\text { e }\end{array}$ & Negative & & \\
\hline \multirow{2}{*}{$\begin{array}{c}\text { Involved in a } \\
\text { fight } \\
\text { (aggressor) }\end{array}$} & No & 60 & 23 & 10 & 9 & 44 & 12 & 3 & 69 & \multirow{6}{*}{77.8} & \multirow{6}{*}{$\begin{array}{c}* * \\
0.00\end{array}$} \\
\hline & $\%$ & $54.1 \%$ & $46.0 \%$ & $83.3 \%$ & $100 \%$ & $67.7 \%$ & $100 \%$ & $\begin{array}{c}100 \\
\%\end{array}$ & $29.0 \%$ & & \\
\hline \multirow{2}{*}{$\begin{array}{l}\text { Victim to an } \\
\text { assault }\end{array}$} & No & 51 & 27 & 2 & 0 & 21 & 0 & 0 & 169 & & \\
\hline & $\%$ & $45.9 \%$ & $54 \%$ & $16.7 \%$ & $.0 \%$ & $32.3 \%$ & $.0 \%$ & $.0 \%$ & $71 \%$ & & \\
\hline \multirow{2}{*}{ Total } & No & 111 & 50 & 12 & 9 & 65 & 12 & 3 & 238 & & \\
\hline & $\%$ & $100 \%$ & $100 \%$ & $100 \%$ & $100 \%$ & $100 \%$ & $100 \%$ & $100 \%$ & $100 \%$ & & \\
\hline
\end{tabular}

** $P$ value $<0.01=$ highly significant

Table 6: Chi square statistical analysis of the relation between type of abused drug and level of education

\begin{tabular}{|c|c|c|c|c|c|c|c|c|c|c|c|}
\hline \multirow{2}{*}{\multicolumn{2}{|c|}{ Level of education }} & \multicolumn{8}{|c|}{ Type of abused drug } & \multirow[b]{2}{*}{$\chi^{2}$} & \multirow[b]{2}{*}{$\boldsymbol{P}$} \\
\hline & & $\begin{array}{c}\text { Cannabis } \\
30\end{array}$ & $\begin{array}{c}\text { Tramadol } \\
12\end{array}$ & $\begin{array}{c}\text { Sedatives } \\
1\end{array}$ & $\begin{array}{c}\text { Stimulants } \\
0\end{array}$ & $\begin{array}{c}\begin{array}{c}\text { Cannabis } \\
+ \\
\text { Tramadol }\end{array} \\
5\end{array}$ & $\begin{array}{c}\begin{array}{c}\text { Cannabis } \\
\text { +BDZs }\end{array} \\
0\end{array}$ & $\frac{\text { Opiate }}{1}$ & $\frac{\text { Negative }}{31}$ & & \\
\hline Illiterate & $\%$ & $27.0 \%$ & $24.0 \%$ & $8.3 \%$ & $.0 \%$ & $7.7 \%$ & $.0 \%$ & $33.3 \%$ & $13.0 \%$ & \multirow{7}{*}{62.5} & \multirow{7}{*}{$\begin{array}{c}* * \\
0.00\end{array}$} \\
\hline Just Read & No & 31 & 18 & 3 & 3 & 31 & 3 & 2 & 75 & & \\
\hline \&write & $\%$ & $27.9 \%$ & $36.0 \%$ & $25.0 \%$ & $33.3 \%$ & $47.7 \%$ & $25 \%$ & $66.7 \%$ & $31.5 \%$ & & \\
\hline \multirow{2}{*}{ Higher } & No & 11 & 0 & 5 & 0 & 3 & 0 & 0 & 45 & & \\
\hline & $\%$ & $9.9 \%$ & $.0 \%$ & $41.7 \%$ & $.0 \%$ & $4.6 \%$ & $.0 \%$ & $.0 \%$ & $18.9 \%$ & & \\
\hline \multirow{2}{*}{ Total } & No & 111 & 50 & 12 & 9 & 65 & 12 & 3 & 238 & & \\
\hline & $\%$ & $100.0 \%$ & $100.0 \%$ & $100.0 \%$ & $100.0 \%$ & $100.0 \%$ & $100.0 \%$ & $100.0 \%$ & $100.0 \%$ & & \\
\hline
\end{tabular}

** $P$ value $<0.01=$ highly significant

Table 7: Chi square statistical analysis of the relation between type of abused drug and job

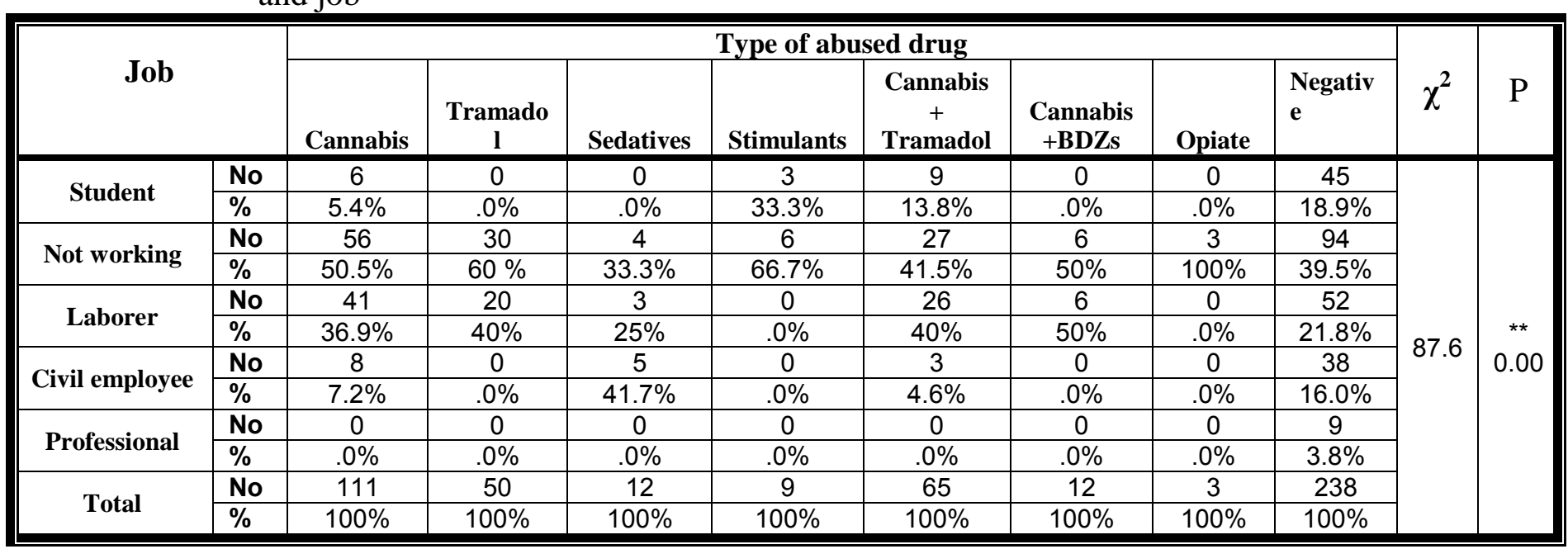

$* * P$ value $<0.01=$ highly significant 
Table 8: Chi square statistical analysis of the relation between ISS and results of drug screening tests

\begin{tabular}{|c|c|c|c|c|c|c|c|c|}
\hline \multirow{2}{*}{\multicolumn{2}{|c|}{$\begin{array}{c}\text { Results of drug } \\
\text { screening }\end{array}$}} & \multicolumn{5}{|c|}{ ISS } & \multirow{2}{*}{$\chi^{2}$} & \multirow{2}{*}{$\mathbf{P}$} \\
\hline & & Minor & Moderate & Serious & Sever & unsurvivable & & \\
\hline \multirow{2}{*}{ Positive } & No & 3 & 186 & 41 & 29 & 3 & \multirow{6}{*}{85.93} & \multirow{6}{*}{0.00} \\
\hline & $\%$ & $100.0 \%$ & $44.7 \%$ & $89.1 \%$ & $90.6 \%$ & $100.0 \%$ & & \\
\hline \multirow{2}{*}{ Negative } & No & 0 & 230 & 5 & 3 & 0 & & \\
\hline & $\%$ & $.0 \%$ & $55.3 \%$ & $10.9 \%$ & $9.4 \%$ & $.0 \%$ & & \\
\hline \multirow{2}{*}{ Total } & No & 3 & 416 & 46 & 32 & 3 & & \\
\hline & $\%$ & $100 \%$ & $100 \%$ & $100 \%$ & $100 \%$ & $100 \%$ & & \\
\hline
\end{tabular}

Table 9: Chi square statistical analysis of the relation between ISS and admission to hospital:

\begin{tabular}{|c|c|c|c|c|c|c|c|c|}
\hline \multirow{2}{*}{\multicolumn{2}{|c|}{$\begin{array}{c}\text { Hospital } \\
\text { admission }\end{array}$}} & \multicolumn{5}{|c|}{ ISS } & \multirow{2}{*}{$\chi^{2}$} & \multirow{2}{*}{$\mathbf{P}$} \\
\hline & & Minor & Moderate & Serious & Sever & unsurvivable & & \\
\hline \multirow{2}{*}{ Yes } & No & 0 & 0 & 43 & 29 & 0 & \multirow{6}{*}{455.193} & \multirow{6}{*}{$\begin{array}{c}* * \\
0.00\end{array}$} \\
\hline & $\%$ & $.0 \%$ & $.0 \%$ & $93.5 \%$ & $90.6 \%$ & $.0 \%$ & & \\
\hline \multirow{2}{*}{ No } & No & 3 & 416 & 3 & 3 & 3 & & \\
\hline & $\%$ & $100 \%$ & $100 \%$ & $6.5 \%$ & $9.4 \%$ & $100 \%$ & & \\
\hline \multirow{2}{*}{ Total } & No & 3 & 416 & 46 & 32 & 3 & & \\
\hline & $\%$ & $100 \%$ & $100 \%$ & $100 \%$ & $100 \%$ & $100 \%$ & & \\
\hline
\end{tabular}

Table (1) shows that the total number of cases during the period of the study was (500) cases, males represented the majority of cases; their percent was $90 \%$. The most entangled age group was $18-<40$ years $(66 \%)$; while the least one was12 -< 18 years $(13.8 \%)$. According to jobs; $45.2 \%$ of the patients were not working followed by laborers $(29.6 \%)$. Regarding education; $38 \%$ of cases had technical education; and $33.2 \%$ of the cases could just read and write. More than half of the cases $(65 \%)$ were from rural areas while only $35 \%$ were from urban areas. $62.6 \%$ of the cases were moderate to heavy cigarettes smokers.
Table (2) shows circumstances of the injury; where $54 \%$ of the cases were victims to assaults and $46 \%$ were involved in fights (aggressors). Regarding history of previous legal troubles; $29.2 \%$ of the cases had a positive history either related to violent acts or drug abuse. Also; fig. (1) shows that more than half of the cases $(52.4 \%)$ tested positive for illegal drugs abuse.

Fig. (2) represents types of drugs of abuse detected in injured subjects; where the highest percent among the positive cases was of cannabis dependent injured subjects (22.2\%), followed by combination of cannabis and tramadol (13\%); 
tramadol only in $10 \%$ of the cases and the least percent was of opiate in $0.6 \%$ of the cases.

Table (3) reveals injury pattern of the injured subjects; where that $73.2 \%$ of the cases were injured by blunt instruments and $15.6 \%$ were injured by sharp ones. Nearly half of the cases $(49.8 \%)$ had more than one type of external injury varying between abrasions, contusions, abraded contusions, contused wounds, cut wounds, stab wounds and firearm wounds. Injuries were distributed in different sites of the body in $52.6 \%$ of the cases (head, neck, chest, abdomen and extremities). As regard to type of internal injuries; factures and hemorrhages were found in equal percent of cases (9.2\% for each). According to ISS; the majority of cases $(83.2 \%)$ were of the moderate degree. Death occurred in 3 cases $(0.6 \%)$ that were of the unsurvivable degree.

Table (4) clarified a highly significant relation between different age groups and results of drug screening tests $\left(\chi^{2}=15.5\right.$ and $P$ value $<0.01)$; where the highest percent of positive drug screening tests $(68.3 \%)$ were in the age group $18-<40$ years, followed by $24.8 \%$ in the age group $40-\leq 55$ years.

Table (5) shows a highly significant relation between type of drug abuse and circumstances of injury $\left(\chi^{2}=77.8\right.$ and $P$ value < 0.01). All injured subjects dependent on opiate, stimulants and a combination of cannabis and benzodiazepines were involved in a fight (aggressors). More than half of cannabis abuse subjects (54\%) were aggressors. On the other side; $54 \%$ of the tramadol abuse cases were victims to assaults.

Table (6) reveals that education level had a highly significant relation with type of drug abuse $\left(\chi^{2}=62.5\right.$ and $P$ value $\left.<0.01\right)$. Most of the drug abuse cases -regardless of type of drug - had technical education: $75 \%$ of cases with a combination of cannabis and benzodiazepines abuse, followed by $66.7 \%$ of stimulants abuse group; then $40 \%$ of tramadol group and finally $35.1 \%$ of cannabis abuse group. On the other side; $41.7 \%$ of sedatives abuse group had higher education. $66.7 \%$ of opiate abuse group could just read and write; followed by $47.7 \%$ of cases with a combination of cannabis and tramadol abuse.

Table (7) shows that jobs were highly significantly related to type of drug abuse $\left(\chi^{2}=87.6\right.$ and $P$ value $<0.01)$; where all opiate abuse cases, $66.7 \%$ of stimulants abuse cases, $60 \%$ of tramadol abuse cases and $50.5 \%$ of cannabis abuse group were not working. On the contrary; $41.7 \%$ of sedative abuse cases were civil employee.

Table (8) demonstrates a highly significant relation between ISS and results of drug screening tests $\left(\chi^{2}=\right.$ 85.93 and $P$ value $<0.01)$. The highest percent of unsurvivable, sever and serious degree cases were positive on drug screening by $100 \%, 90.6 \%, 89.1 \%$ respectively.

Table (9) discusses ISS and its relation with admission to hospital; where it was highly significant $\left(\chi^{2}\right.$ 
$=455.193$ and $P$ value $<0.01)$. All minor and moderate degree cases $(100 \%)$ were not admitted to hospital. On the contrary; $93.5 \%$ of serious degree cases and $90.6 \%$ of sever degree cases were admitted to hospital.

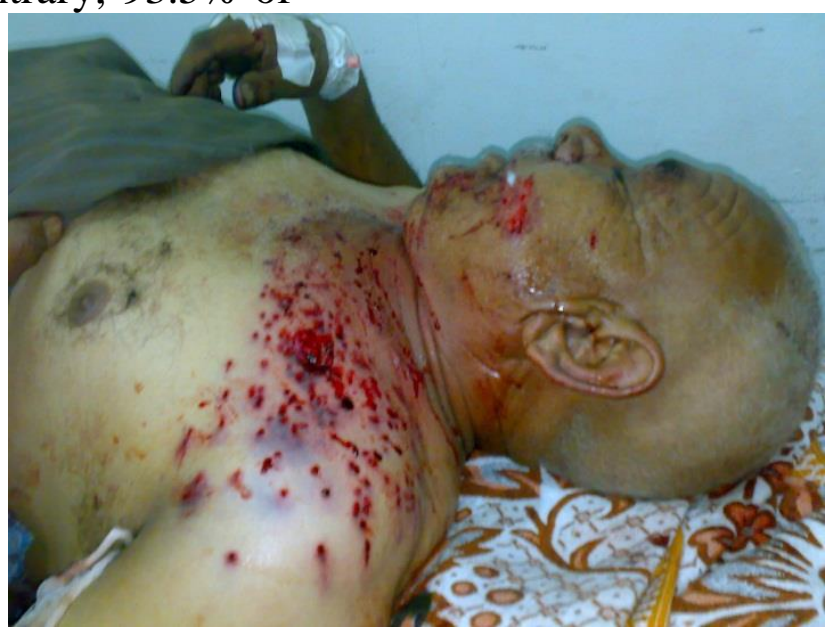

Graph 1: A case of 53 years old male with a gunshot injury (non-rifled weapon) during a quarrel with a sever degree of ISS $(=20)$. The case tested positive for both cannabis and tramadol

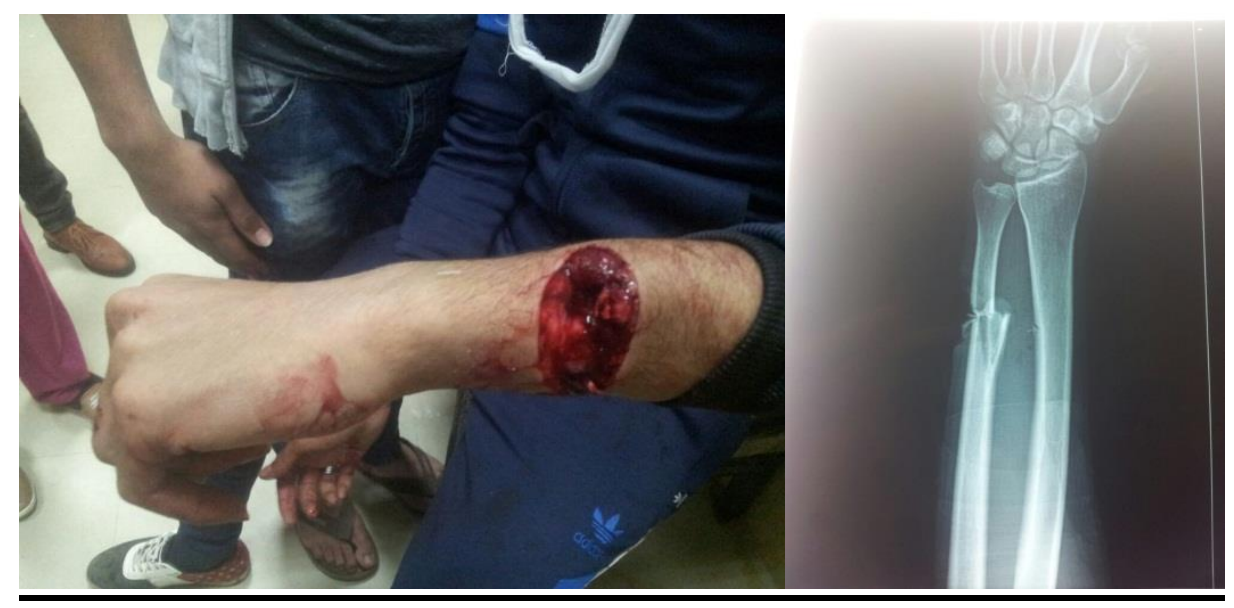

Graph 2: A case of 28 years old male with sharp instrument injury (sword) during a quarrel with serious degree of ISS (=13). Injured subject presented with fracture ulna and cut flexor tendons of the forearm. The case tested positive to cannabis.

\section{DISCUSSION}

The complex relationships between illegal drug abuse and violence have posed challenges to the research community and public health professions for decades.
Understanding the causes, relates, and results of drugs and violence is essential for creating successful public health and law authorization procedures for anticipation and control. In the United States, both the American College of 
Emergency Physicians and the American College of Surgeons recommend routine urine toxicological screening tests of injured subjects admitted to emergency department (Dezman, et al., 2018).

The total number of violent injured cases during the 6 months period of study was 500 cases attended for primary medicolegal report certificate and screened for drug abuse. That was a large number in relation to the relatively short period of the study. The present study revealed that males greatly over numbered females comprising $90 \%$ of the cases. This is because of the presence of male outdoors and in work most of the time facing more stressful situations making them more susibtable to be entangled in violent acts. Indeed; the idea of women being violent is a hard thing for many people to believe, it goes against the stereotype of the passive and helpless female. The commonly and globally observed trend of males being more violent agreed with Korcha et al., 2014; in his review of studies from eight European countries; who stated that injured subjects were predominantly men, representing $63.7 \%$ of the sample. Also; Bowley et al., 2004 in South Africa found that $84.5 \%$ of trauma unit patients were male.

In the current study; the most frequent age group involved in violent acts was the age between $18-<40$ years (66 \%); and represented $68.3 \%$ of the positively screened cases for drugs of abuse.
These findings could be explained by that interpersonal violence is greater for people in early adulthood than people who are older beside to the strong peer influence in this age which drag them in the way of drug abuse and violence. This result coincided with Moore et al., 2008 in their review who found that age 18-40 years showed the highest percent for substance use and interpersonal violence. The findings also agreed with Bogstrand, et al., 2011 who stated that alcohol and illicit drugs; either alone or in combinations, were more prevalent in the 18-35 years old in injured cases admitted to a Norwegian emergency department. Also; Socie et al., 2012 found that among trauma cases reported to the Ohio Trauma Registry; those younger than 45 years of age were $65 \%$ more likely to use drugs than those 45 years or older.

The current study showed that $65 \%$ of victims were from rural areas and $35 \%$ from urban areas. The higher rate of practicing violence in rural areas may be due to the rural nature of Menoufia governorate and low socioeconomic standards associated with low levels of education and culture. Violence and abuse are critical problems and their effects in rural areas are often exacerbated by limited access to support services for victims, a lack of acceptance for alternative lifestyles, distance, transportation barriers, the stigma of abuse, lack of available shelters and affordable 
housing, poverty as a barrier to care, and other challenges.

The previous explanation of how does poverty and low socioeconomic standards in rural areas relate to violence and abuse; coincided with a report from the U.S. Department of Justice, 2014 which stated that rates of violent victimization are associated with poverty level and living in poor households, more than double the rate of violent victimization in communities with high-income.

The current study revealed that $38 \%$ of the cases had technical education and $33.2 \%$ could just read and write. These findings agreed with Korcha et al., 2014 in their study about injured subjects in the ER with drug dependence who found that less than a third of subjects had obtained a college education. Among cannabis positive group; the percent of cases without work reached $50.5 \%$. These results coincided with Compton et al., $\mathbf{2 0 0 7}$ in their study on a representative sample of the adult population of the United States; and found that drug abuse and dependence were greater among those in the lowest income and education category. Also Ayllón and Ferreira-Batista, 2018 stated that a positive relationship existed between the level of unemployment and cannabis consumption among young Europeans.

Drug screening tests for illegal drugs revealed that more than half of the injured subjects $(52.4 \%)$ were positive on screening. This demonstrates that involvement in drug abuse can increase the risks of being both a victim and/or perpetrator of violence, while experiencing violence can increase the risks of initiating illicit drug use, and the relationship between drugs and violence is causal and/or an association, with the two being linked through shared risk factors (Krug et al., 2002). This result was similar to Carrigan et al., 2000 in England who stated that $51 \%$ of trauma cases seen in the resuscitation room have a positive toxicological screen for illicit drug use. Also; Zautcke et al., 2002 study conducted with emergency room samples in Illinois, USA using urine toxicology screens report an overall incidence of illicit drugs of $42.6 \%$. CordovillaGuardia et al., 2017 found that of all injured subjects admitted to a trauma hospital in Spain and screened, $31.3 \%$ were positive for drugs other than alcohol. This variability may be due to different localities of studies and variable levels of health education.

In addition; Fawzi, 2011 on her study carried on the patients presented to the Poison Control Center of Ain Shams University Hospitals (PCC-ASU) Egypt with acute tramadol toxicity and those referred from the emergency unit (ER) surgery department of Ain Shams University Hospitals presented with trauma associating violent action with the suspicion of drug abuse for toxicological assessment; she stated that tramadol abuse is highly associated different 
forms of violence acts as fights and domestic violence (33\%).

Cannabis was the most used drug of abuse among violent injured cases. Cannabis abuse subjects represented $22.2 \%$ of the studied cases. This may be due to its wide availability, cheaper price and easy access in our society compared with other types of illegal drugs.

The second most common drug of abuse in this study was tramadol, where it was combined with cannabis in $13 \%$ of the cases; and was found alone in $10 \%$ of the cases; while opiate represented the least percent of the cases $(0.6 \%)$. This may be due to the fact that opioids are more expensive and less available than tramadol; so tramadol represent the ideal substitute for those who are seeking for the same effect.

Our results were similar to results of Yassa et al., 2009's study which was conducted on students of secondary schools and drivers in Assiut province, Egypt. They found that $11.6 \%$ of students and $12 \%$ of drivers tested positive for cannabis abuse; and $51.7 \%$ of positive cases were 21 to $<31$ years old.

The current study results were relatively lower than Hamdi et al., 2013 in their study on a sample of the Egyptian population aged $15+\mathrm{s}$ to determine the prevalence of substance misuse in susceptible population subgroups. He found that of the 3852 subjects who were found to use alcohol and/or other substances, 2941 use cannabinoids (77.3\%). El-Sawy et al., 2010 stated that Among males patients of drug abuse who attended outpatient clinic in Neuropsychiatry Department in Tanta University Hospital, bhang and hashish ranked first $(64.89 \%)$.

Hamdi et al., 2016 in their study on a community sample of the Egyptian adult population (16 years and older) to study the current prevalence of substance use and abuse; stated that cannabis was the commonest in all regions. $77 \%$ of the substance users were using Cannabis.

Peden et al., 2000 in South Africa also found that the incidence of cannabis abuse was $34.2 \%$ of the injured patients presenting at the trauma unit. Moreover; Sanjuan et al., 2014 found that $60 \%$ of emergency department patients in six hospitals in the United States were cannabis users. Moore et al., 2008 and Reingle et al., 2012 stated that marijuana was positively associated with partner violence perpetration and victimization. On the other side, Bogstrand et al., 2011 reported that only $6.2 \%$ of injured cases in emergency department screened positive for cannabis; and the most prevalent psychoactive substance was alcohol (27\%). This difference may be due to the fact that native and cultural variables have high impacts on consumption patterns of a population.

Cannabis use impairs cognition and creates perceptual distortions; consequently, people who have used it may interpret others actions as aggressive even if they are not, and respond combatively (Jhonson 
et al., 2017). Also, cannabis may impair the ability to tamp down aggressive impulses, and thereby increase the risk for aggressive behavior in conflict situations (Yanowitch and Coccaro, 2011). Relatedly, cannabis use increases heart rate, and the physiological arousal associated with an increased heart rate may increase the likelihood of aggressive behavior (Moore, and Stuart, 2005). Among vulnerable individuals; cannabis use could be associated with a sustained psychotic state that is clinically indistinguishable from schizophrenia; also it results in increased synaptic dopamine activity; which seems to reveal itself as an initial euphoricanxiolytic effect, followed later by psychotic manifestations (Vorugantia et al., 2001; D'Souza et al., 2009). The pharmacological effect of $\Delta^{9}$-THC (tetrahydrocannabinol- the active ingredient of cannabis) that acts upon CB1 receptor (cannabinoid receptor 1) in the VTA (ventral tegmental area) to evoke burst firing leading to dopamine increases in striatal areas and the NACc (nucleus accumbens) which explains reward phenomenon after its use. CB1 receptor mediated modulation of dopamine levels in the pre-frontal cortex has also been demonstrated (Sami et al., 2015). Dopamine is known to have a role in aggression by being involved in the initiation and performance of aggressive behavior (Siever, 2008).

Regarding cigarette smoking; $62.6 \%$ of the study cases had positive history of moderate to heavy cigarette smoking. Smoking is known to be a primary step for drug abuse and dependence. This makes smoking a strong risk factor for beginning of violence. The current study results agreed with Yassa et al., 2009 who stated that $83.3 \%$ of positive cannabis cases were heavy smokers while $15 \%$ were moderate smokers; and cigarette smoking is a major step for cannabis abuse.

Within the brain reward circuit, nicotinic cholinergic and mesolimbic dopaminergic systems interact closely especially in the VTA and NAc. Acting through the nAChRs (nicotinic receptors), nicotine increases the release of most neurotransmitters including glutamate, GABA, acetylcholine, dopamie, norepinephrine, and serotonin. As a consequence, nicotine modifies a large number of physiological processes such as locomotion, nociception, anxiety, learning and memory, as well as produces several behavioral responses directly related to its addictive properties, including rewarding effects and physical dependence (Berrendero et al., 2010). The current findings agreed with Peden et al., 2000 who stated that although more than two-thirds of the injured cases in his study acknowledged smoking; however this habit may not itself be a risk factor for injury, it may indicate a 'risk-taking' personality since there was a definite association between cigarette smoking and the use of 
both alcohol and drugs in this cohort of injured patients.

In this study, we found that all cases dependent on opiate, stimulants, combined cannabis with benzodiazepines abuse and 54.1\% of cannabis dependent group were involved in a fight (aggressors). The possible explanation may be the fact that drugs and violence represent one form of deviance. Drug abuser may be more likely to engage in other deviant behaviors as violence (Baskin-Sommers and Sommers, 2006).

The results of this study included a strong relation between injury severity score and results of drug screening (positive or negative) where all cases of the unsurvivable degree and majority of sever and serious degree cases were positive on screening. There is due to the fact that illegal drugs affect performance and behavior, reduce awareness and impair cognitive and motor function and therefore increase injury risk and severity. These results agreed with Cordovilla-Guardia, et al., 2017 who found that positive screened patients over numbered negative ones in the sever degree of ISS. Socie et al., 2012 also found that injury severity was significantly worse among substance users than nonusers.

\section{CONCLUSION}

The present study revealed that the majority of the cases attended to Menoufia University Hospital with violent injuries were middle aged males from rural areas, with low educational level and not working. More than half of the cases had positive toxicological screening tests where cannabis was the most commonly abused drug, followed by a combination of cannabis and tramadol; the highest percent of positive screened cases was in the age group $18-<40$ years. Blunt instruments were more widely used in violent acts than sharp ones with variable types of external injuries.

A significant relationship was found to exist between severity of injury- as determined by ISS- and presence of drugs of abuse. Also; admission to hospital was significantly related to severity of injury. Morbidity and mortality as a result of trauma is a major burden for our country.

\section{LIMITATIONS AND \\ RECOMMENDATIONS}

The current study used immunoassays rapid tests on urine samples, which do not give information on the amount of drug consumed or recency of consumption because drug metabolites may be excreted for days and even weeks after use; so we could only document prevalence of use or dependence.

Thus the analysis of the quantity of drug used and its impact on the risk of injury is a subject that should be targeted in future studies. We recommend that all violent injured subjects be screened routinely regarding their illicit drug usage. Such monitoring would not only assist clinicians in assessing and managing patients, but would also monitor substance abuse trends 
and quickly identify emerging problems.

In general, the present data only represent a "picture" of a sample and are not representative of the general population. The current findings have implications for how public health problems of injury and substance abuse should be taken into consideration in research and emergency patient care protocols. Doctors have a responsibility both to highlight awareness of this problem and to promote substance abuse and injury prevention education. Increased drug awareness education must be part of the strategies to improve the health of the country.

More over; there should be wide spread use of information, education and communication in rural areas so as to contradict the myths about drug use and for declaration of its alleged usages. Health authorities in Egypt need to observe misuse of prescription medicinal drugs for potential abuse and to adopt policies to limit potential abuse. School- and community- based prevention programs are highly required in Egypt as a first-line strategy in the fight against drug abuse.

Conducting sessions to educate new graduates and students of the faculty of pharmacy and medicine are needed to sensitize them to the dangers of drug abuse phenomenon and inform them about what they could be subjected to by means of practical training in pharmacies and clinics.
Integrated programs should be designed for school and university students to raise awareness of the dangers of drug addiction, its subsequent health and psychological problems and the resultant wrong practices of violence and aggression against others.

The media should be directed to raise awareness against violence and bullying practices and to clarify that these acts are far from our customs, traditions, and teachings of religions. Such misdeeds may lead to legal accountability and penalties. Also; It is worthy for the media to stop exporting models of violence, bullying and gun users as heroes of drama because youth tend to imitates them and practice the same aggressive unaccepted acts.

It is a persistent need to develop a hotline to communicate with officials to report against violent acts and crimes and for the rescue of victims.

Injuries due to violent acts are strongly associated with increased mortality, more complications, longer hospital stays, and ultimately greater economic costs, so there is a deep need to reduce the wrong practices of violence and the consequent physical and moral burden on both individuals and community.

On the other hand, the government is required to address the risk factors leading to both the problems of addiction and violence, the most important of which is to create jobs for young people and reduce the problem of 
unemployment and leisure time, which is often abused. The government should also work to raise the level of education and find new ways to attract children and youth to schools and reduce their escape from them.

Finally, medical convoys to the villages and the remote places for early detection and dealing with drug abuse patients and violence victims is one of the most effective measures to deal with the real problem holders. Menoufia University was one of the leading institutions in this field, where the doctors of the university patrol the villages and carry out both awareness and therapeutic sessions. The University has also developed an outpatient clinic for treatment and follow up of drug abuse patients which belongs to Forensic Medicine And Clinical Toxicology Department, Faculty Of Medicine.

\section{FUND}

This work was funded by Menoufia University.

\section{REFERENCES}

Atkinson, A.; Anderson, Z.; Hughes, K. et al., (2009): World health report on interpersonal violence and illicit drugs. Geneva, World Health Organization.

Ayllon, S. and Ferreira-Batista, N.N. (2018): Unemployment, drugs and attitudes among European youth. Journal of health economics, 57:236-248.
Baskin-Sommersa, A. and Sommers, I. (2006): The cooccurrence of substance use and high-risk behaviors. Journal of Adolescent Health, 38:609-611.

Berrendero, F.; Robledo, P.; Trigo, J.M. et al., (2010): Neurobiological mechanisms involved in nicotine dependence and reward: participation of the endogenous opioid system. Neurosci Biobehav Rev, 35(2): 220-231.

Bogstrand, S.T.; Normann, P.T.; Rossow, I. et al., (2011): Prevalence of alcohol and other substances of abuse among injured patients in a Norwegian emergency department. Drug and Alcohol Dependence, 117:132-138.

Bowley, D.M.; Rein, P.; Cherry, R. et al., (2004): Substance abuse and major trauma in Johannesburg. SAJS, 42(1):710.

Carrigan, T.D.; Field, H.; Illingworth, R.N. et al., (2000): Toxicological screening in trauma. Hamer JAccidEmerg Med, 17:33-37.

Compton, W.M.; Thomas, Y.F.; Stinson, F.S. et al., (2007): Prevalence, correlates, disability and comorbidity of DSM-IV drug abuse and dependence in the United States. Results from the national epidemiologic survey on alcohol and related 
conditions. Arch Gen

Psychiatry, 64:566-576.

Cordovilla-Guardia, S.; LardelliClaret, P.; Vilar-López, R. et al., (2017): The effect of central nervous system depressant, stimulant and hallucinogenic drugs on injury severity in patients admitted for trauma. Gaceta Sanitaria, 31:1-6.

Dawson, B. and Trapp, R.G. (2001): Basic and clinical biostatistics: lange medical books. Oxford, London. Boston, McGraw-Hill, Medical Publishing Division. 3rd edition, Chapter 7-9, pages: 161-218.

Dezman, Z.D.W.; Gorelick, D.A.; Soderstrom, C.A. et al., (2018): Test characteristics of a drug CAGE questionnaire for the detection of non-alcohol substance use disorders in trauma inpatients. Injury, Int. J. Care Injured, 49(8):1538-1545.

D'Souza, D.C.; Sewell, R.A. and Ranganathan, M. (2009): Cannabis and psychosis/ schizophrenia: human studies. Eur. Arch. Psychiatry Clin. Neurosci, 259:413-431.

El-Sawy, H. Abdel Hay, M. and Badawy, A. (2010): Gender Differences in Risks and Pattern of Drug Abuse in Egypt Egypt $\mathbf{J}$ Neurol Psychiat Neurosurg. 47(1): 413-418

Fawzi; M.M. (2011): Some medicolegal aspects concerning tramadol abuse: The new Middle East youth plague 2010. An Egyptian overview. Egyptian Journal of Forensic Sciences, 1: 99-102

Goldstein, P.J.; Brownstein, H.H.; Ryan, P.J. et al., (1989): Crack and homicide in New York City, 1988: a conceptually based event analysis. Contemp Drug Probl., 16(4):651-687.

Hamdi, E.; Gawad, T.; Khoweiled, A.; Sidrak A.E.; Amer, D.; Mamdouh, R. et al., (2013): Lifetime Prevalence of Alcohol and Substance Use in Egypt: A Community Survey. Substance Abuse, 34(2): 97-104.

Hamdi, E.; Sabry, N.; Sedrak, A.; Khoweiled, A.; Loza, N.; Rabie, M. et al., (2016): Sociodemographic Indicators for Substance Use and Abuse in Egypt. J Addiction Prevention; 4(1): 1-8.

Harford, T.C.; Chen, C.M. and Grant, B.F. (2016): Otherand self-directed forms of violence and their relationship with number of substance use disorder criteria among youth ages 12-17: results from the national survey on drug use and health. J Stud Alcohol Drugs, 77(2):277-286.

Harrell, E.; Langton, L.; Berzofsky, M. et al. (2014): Household Poverty and Nonfatal Violent Victimization, 2008-2012 U.S. Department of 
Justice, Office of Justice Programs, Bureau of Justice Statistics.

Johnson, R.M.; LaValley, M. Schneider, K.E. et al., (2017): Marijuana use and physical dating violence among adolescents and emerging adults: A systematic review and meta-analysis. Drug and Alcohol Dependence, 174:4757.

Korcha, R.A.; Cherpitel, C.J.; Witbrodt, J.; Borges, G.; Hejazi-Bazargan, S.; Bond, J.C. et al., (2014): Violencerelated injury and gender: The role of alcohol and alcohol combined with illicit drugs. Drug and Alcohol Review, 33:43-50.

Krug, E.; Dahlberg, L.; Mercy, J. et al., (2002): Violence: a global public health problem. World report on violence and health, Geneva: World Health Organization, 1:1-22.

McGinty, E.E.; Choksy, S. and Wintemute, G.J. (2016): The relationship between controlled substances and violence. Epidemiologic Reviews, 38(1):5-31.

Moore, T.M. and Stuart, G.L. (2005): A review of the literature on marijuana and interpersonal violence. Aggression and Violent Behavior, 10(2):171-192.
Moore, T.M.; Stuart, G.L.; Meehan, J.C. et al., (2008): Drug abuse and aggression between intimate partners: A meta-analytic review. Clinical Psychology Review, 28(2):247274.

Peacock, A.; Leung, J.; Larney, S.; Colledge, S.; Hickman, M.; Rehm, J. et al., (2017): Global statistics on alcohol, tobacco and illicit drug use: $\quad 2017 \quad$ status report . Addiction, 113:19051926

Peden, M.; Spuy, J.V. and Smith, P. (2000): Substance abuse and trauma in Cape Town. South African Medical Journal, 90(3):251-255.

Pérez, K.; Santamarĩ̃na-Rubio, E.; Rodrguez-Martos, A.; Brugal, T.; Ricart I.; Suelves J.M. et al., (2009): Substance use among non-fatally injured patients attended at emergency departments in Spain. Drug Alcohol Dependence, 105:194201.

Reingle, J.M.; Staras, S.A.; Jennings, W.G. et al., (2012): The relationship between marijuana use and intimate partner violence in a nationally representative, longitudinal sample. Journal of Interpersonal Violence, 27(8):1562-1578.

Sami, M.B.; Rabiner, E.A. and Bhattacharyy, S. (2015): Does cannabis affect dopaminergic signaling in the human brain? A systematic review of evidence 
to date. European

Neuropsychopharmacology

25:1201-1224.

Sanjuan, P.M.; Rice, S.L.; Witkiewitz, K. et al., (2014): Alcohol, tobacco and drug use among emergency department patients. Drug and Alcohol Dependence, 138:32-38.

Siever, L.J. (2008): Neurobiology of Aggression and Violence. Am J Psychiatry, 165:429-442.

Socie, E.; Duffy, R.E. and Erskine, T. (2012): Substance use and type and severity of injury among hospitalized trauma cases: Ohio, 20042007.Journal of studies on alcohol and drugs, 73(2):260267.

Vorugantia, L.N.P.; Slomkab, P.; Zabelb, P. et al., (2001): Cannabis induced dopamine release: an in-vivo study.
Psychiatry
Research:
Neuroimaging
Section,
107:173-177.

Yanowitch, R. and Coccaro, E.F. (2011): The neurochemistry of human aggression. Adv. Genet., 75:151-169.

Yassaa, H.A.; Dawood, A.A.; Shehata, M.M. et al., (2009): Risk factors for bango abuse in Upper Egypt Environmental Toxicology and Pharmacology 28:397- 402

Zautcke, J.L.; Coker, S.B.; Morris, R.W. et al., (2002): Geriatric trauma in the state of Illinois: substance use and injury patterns. Am. J. Emerg. Med., 20(1):14-17. 


\section{الملخص العربيى}

تقييم علاقة العنف بين الأفراد وإدمان المخدرات فى الحالات الواردة لمستثفي جامعة المنوفية المختة

(دراسة مستقبلية)

ريهام حسن الفرعوني و نجوي محمود حبيب

قسم الطب الثرعي و السموم الاكلينيكيهـ كليه الطب-جامعه المنوفيه

يرتبط تعاطي المخدر ات و العنف بين الأفر اد ببعضهما البعض بقوة حيث أن ادمان الثخص للمخدرات يزيد من فرص ان يكون الفرد مرتكبا للعنف أو ضحية له. إن أدمنن المخدرات يعتبر عامل مساهم في جميع انواع الإصابات تقريبا وذللك لما يحدثه من تغير ات سيئة على العقل و السلوك البشري. هدفت هذه الدراسة إلى دراسة

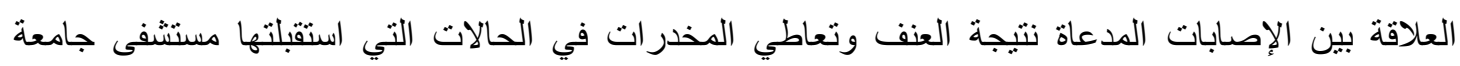
المنوفية وأيضا دراسة نسب انتشار ونمط تعاطي المخدرات بين هذه الحالات خلال ستة أنشهر (من الأول من

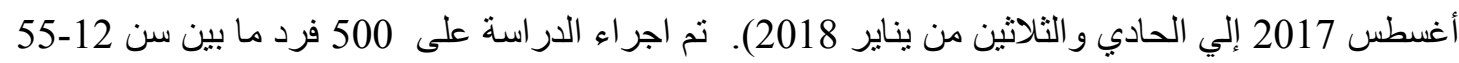
عاما بعد اخذ الموافقة الواعية للحالات التى وردت مستشفى جامعة المنوفية لأخذ تقرير طبى شرعى عن الحالة . تم عمل استمارة طبية لكل حالة تشمل بيانات المصاب الديموجر افية وبيانات الأصابة (كنو عها ومكانها وسببها). و أيضا الفحص الإكلينيكى للاصابات وتم تقسيم الحالات تبعا لدرجة الخطورة إلى حالات بسيطة، منوسطة، خطيرة وممينة. كما تم عمل استنيان عن تعاطى مواد المخدرات. تم أيضا أخذ عينة بول لكل حالة و فحصها

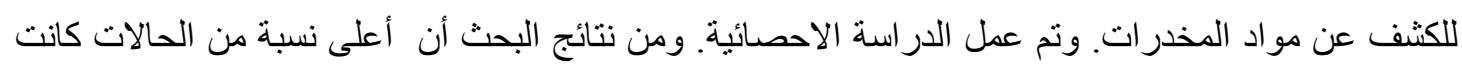
بين الذكور(90\%)، 66\%من الحالات كانت فى الفئة العمرية 18-40 عاما وغالبيتهم لا يعملون بنسبة (\%73,2\%)، وكانوا حاصلين على مؤهل منوسط (38\%) أو غير متعلمين (33,2\%). أغلب الحالات يقيمون

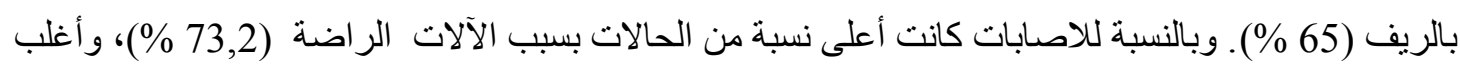
حالات الدراسة كانت منوسطة الخطورة (83,2 \% \%)، وتم حجز 14,4 \% من من الحالات بالمستشفي. ويمثل الحشيش أعلى نسبة من مواد تعاطى المخدرات ، يليه إستخدام الحشيش والترامادول بينما كانت مشتقات

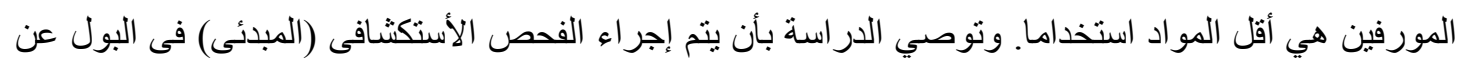

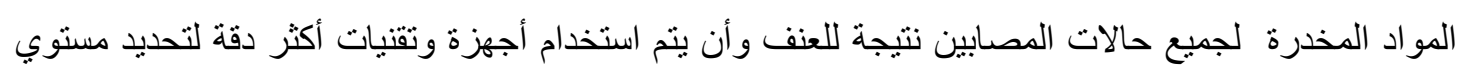
مو اد الادمان في الدم وذلك له أهمية فى إكتشاف الحالات و الحد من مشكلة انتشار هذه المو اد و المشاكل الناجمة عن استخدامها فى المجتمع. 